\title{
SLOPOL6:
}

\section{A Macroeconometric Model For Slovenia}

Klaus Weyerstrass, (E-mail: weyerstr@ihs.ac.at), Institute for Advanced Studies, Austria Reinhard Neck, (E-mail: reinhard.neck@uni-klu.ac.at), Klagenfurt University, Austria

\begin{abstract}
Slovenia entered the European Union in 2004 and was the first country of the ten new members to enter the Euro Area in 2007. As Slovenia was part of Communist Yugoslavia until 1991, the economic history of this country to some extent started after that date. This provides difficulties for attempts to discover empirical regularities to be exploited for forecasting and policy analysis. Nevertheless, in this paper, we describe a macroeconometric model for Slovenia, called SLOPOL6. It was estimated using most recent quarterly data and rests on up-to-date econometric methodology, including stationarity and cointegration analysis. The model has already been used successfully for simulations of alternative monetary and fiscal policy measures.
\end{abstract}

\section{INTRODUCTION}

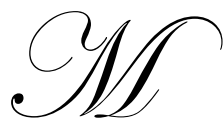

ay 1, 2004, Slovenia joined the European Union together with nine other countries, seven of which from Central and Eastern Europe. Although trade barriers were removed to a large extent already during the accession negotiations, participation in the EU is further fostering economic integration of the new member states with each others and with incumbent Union members. One important integration aspect concerns the monetary policy framework. From the first day of membership onwards, the new member countries have been participating in the European Economic and Monetary Union (EMU), albeit with a derogation. Being EMU members does not imply introducing the euro immediately. In order to have the right to adopt the common currency, the new EU member states are required to fulfill the convergence criteria set out in the Maastricht Treaty. In May 2006, both the European Commission and the European Central Bank decided that Slovenia fulfilled all relevant criteria. Thus, on 1 January 2007, Slovenia was the first of the new members to enter the Euro Area. This is remarkable as Slovenia so far is the only former Communist country having the euro as legal tender. Apart from monetary policy, an evaluation of fiscal policy is important for membership in the EMU as the country has to fulfill the requirements of the Stability and Growth Pact of the EMU.

As for other countries, it is desirable to have a tool for forecasting macroeconomic developments over the short and medium run and for evaluating alternative policies aiming at influencing the business cycle, at stabilizing unemployment and inflation and at enhancing growth and employment in Slovenia. A macroeconomic model is such a tool, especially if it is an econometric model based on sound theoretical foundations and estimated with real data of the economy under consideration. To build such a model, it is of crucial importance to have available a data base with sufficiently long time series to provide reliable estimates. For Slovenia, this provides a major problem as this country was part of Communist Yugoslavia until 1991 when it became an independent state and then was transformed into a parliamentary democracy with a market economy. Data before 1991 are based on Communist accounting rules and are not comparable to those of later years. Moreover, many data (especially those from national income accounting) are of dubious quality even for the first years of the transition process. Therefore estimations of behavioral equations for Slovenian aggregates have to rest on data starting around 1995. In order to get estimations with sufficient degrees of freedom, an econometric model for Slovenia has to use quarterly or - where available monthly or higher-frequency data. Here we describe a quarterly macroeconometric model called SLOPOL6, which is a revised and updated version of a series of models we built since the late 1990s, with increasing degrees of sophistication and reliability. These models were used for various purposes of forecasting and especially evaluating 
alternative policies, where simulation and optimization experiments were conducted to arrive at politically relevant insights and policy recommendations (see, e.g., Neck et al. 2004).

\section{VARIABLES OF THE ECONOMETRIC MODEL SLOPOL6}

SLOPOL6 (SLOvenian economic POLicy model, version no. 6) is a medium-sized macroeconometric model of the Slovenian economy. In its current version, it consists of 57 equations of which 21 are behavioral equations and 36 are identities. The former were estimated by ordinary least squares (OLS), using quarterly data for the period 1995:1 until 2005:4. Data for Slovenia were provided by the Slovenian Statistical Office, by the Institute of Macroeconomic Analyses and Development (IMAD), and by the Bank of Slovenia. Euro Area data were taken from the EUROSTAT database, except for the short-term interest rate in the Euro Area, which was extracted from the database of the German Bundesbank. In this Section, we describe the variables used in the model SLOPL6. All data are available from the authors upon request.

\section{Endogenous Variables}

\begin{tabular}{|c|c|}
\hline$A G W N$ & Average gross wage per employee, nominal, SIT / quarter \\
\hline$A G W R$ & Average gross wage per employee, real \\
\hline BUDGETREST & Balance of other, non-allocated government revenues and expenditures \\
\hline$C A N$ & Current account balance, real \\
\hline$C A G D P$ & Current account balance as percentage of real GDP \\
\hline$C A P R$ & Capital stock, real \\
\hline CPI & Consumer price index \\
\hline$C R$ & Private household consumption, real \\
\hline$D E B T$ & Public debt level, nominal \\
\hline DEBTGDP & Public debt level as percentage of nominal GDP \\
\hline$D E F G D P$ & Budget deficit as percentage of nominal GDP \\
\hline DEFICITN & Budget deficit, nominal \\
\hline DEMAND & Total final demand, real; GDPR + IMPR \\
\hline$E M P$ & Employment; 1,000 persons \\
\hline EXR & Exports, real \\
\hline$G D P D E F$ & GDP deflator \\
\hline$G D P N$ & Gross domestic product, nominal \\
\hline$G D P R$ & Gross domestic product, real \\
\hline GINVR & Public investment, real \\
\hline GNFIN & Government consumption according to government financial statistics \\
\hline$G R$ & Government consumption, real \\
\hline GRGDPR & Annual growth rate of real GDP \\
\hline GRYPOT & Annual growth rate of potential GDP \\
\hline ILONGR & Real long term interest rate \\
\hline$I M P R$ & Imports, real \\
\hline INCCORP & Government revenues from corporate taxes, nominal \\
\hline INCOME & Disposable income of private households, nominal \\
\hline INCOMER & Disposable income of private households, real \\
\hline INCTAX & Government revenues from total income taxes, nominal \\
\hline$I N F L$ & CPI inflation rate \\
\hline INTEREST & Payments on outstanding public debt \\
\hline INVENTR & Inventory investment, real \\
\hline$I N V R$ & Investment, real \\
\hline LFORCE & Labor force; 1,000 persons \\
\hline LTIRLN & Nominal long term interest rate \\
\hline$M 3 N$ & Money stock M3, nominal \\
\hline$M 3 R$ & Money stock M3, real \\
\hline NAIRU & Inflation-stable rate of unemployment \\
\hline NETWAGEN & Average net wage, nominal \\
\hline NETWAGER & Average net wage, real \\
\hline PERSINCTAX & Government revenues from personal income taxes, nominal \\
\hline PRINVR & Private gross fixed capital formation, real \\
\hline
\end{tabular}




$\begin{array}{ll}\text { PROD } & \text { Labor productivity } \\ \text { SITEUR } & \text { Nominal exchange rate, SIT per euro } \\ \text { SITEURREAL } & \text { Real exchange rate between Slovenian tolar and euro } \\ \text { SOCCOMP } & \text { Employers' social security contributions, nominal } \\ \text { SOCEMP } & \text { Employees' social security contributions, nominal } \\ \text { SOCTOTAL } & \text { Total social security contributions, nominal } \\ \text { STIRLN } & \text { Nominal short term interest rate (policy instrument and determined in a Taylor-rule type equation in the } \\ & \text { case of flexible interest rates) } \\ \text { TREND_EMP } & \text { Trend employment (labor force minus "natural" unemployment) } \\ \text { UCC } & \text { User cost of capital } \\ \text { ULC } & \text { Unit labor costs } \\ \text { UN } & \text { Unemployment, } 1,000 \text { persons } \\ U R & \text { Unemployment rate, } \% \text { of the labor force } \\ U T I L & \text { Capacity utilization rate } \\ W E D G E & \text { "Tax Wedge"; difference between average nominal gross and net wage per employee } \\ Y P O T & \text { Potential GDP, real }\end{array}$

\section{Exogenous Variables, Not Controllable By Slovenian Policy-Makers}

DEBTADJ

$D E P R$

DUM021

DUM05

DUM992

DUM993

EUR1OY

EUR3M

GDPEUR12

HICPEUR12

TIME

Policy Variables

GINVN

GN

INCTAXRATE

SOCEMPRATE

TRANSFERSN
Possible adjustments to the stock of public debt Depreciation rate of the capital stock Dummy variable, 1 in the first quarter 2002, 0 otherwise Dummy variable, 1 in the year 2005, 0 otherwise Dummy variable, 1 in the second quarter 1999, 0 otherwise Dummy variable, 1 in the third quarter 1999, 0 otherwise Interest rate for 10 years government bonds in the euro area Three-months interest rate in the euro area Real GDP in the euro area Harmonized index of consumer prices in the euro area Linear time trend

Public investment, nominal Government consumption, nominal Average "tax" rate, including income tax and employees' social security contributions Social security contribution rate for employees Transfers to private households, nominal

\section{TESTS FOR STATIONARITY OF THE TIME SERIES}

Next, we report about the results of Augmented Dickey-Fuller tests (ADF), Phillips-Perron tests (PP) and Kwiatkowski-Phillips-Schmidt-Shin tests (KPSS) for stationarity. All variables except for interest rates and population were seasonally adjusted before testing. Variables which are unambiguously stationary according to these tests are denoted with a $\S$, those which are unambiguously non-stationary are given a \&. The decision on lag length was based on the Schwarz information criterion (SIC). We used the test model with a constant and without a deterministic trend. 
Levels

\begin{tabular}{|c|c|c|c|c|c|c|}
\hline Variable & \multicolumn{2}{|c|}{ ADF } & \multicolumn{2}{|c|}{ PP } & \multicolumn{2}{|c|}{ KPSS } \\
\hline & Lags (SIC) & & Bandwidth & & Bandwidth & \\
\hline AGWN \& & 0 & 0.095 & 0 & 0.095 & 5 & $0.842 * * *$ \\
\hline AGWR \& & 0 & -0.865 & 12 & -1.089 & 5 & $0.844 * * *$ \\
\hline CAN $\S$ & 0 & $-4.454 * * *$ & 3 & $-3.672 * * *$ & 4 & 0.141 \\
\hline CAGDP $\S$ & 1 & $-2.013^{* *}$ & 4 & $-3.814 * * *$ & 4 & 0.241 \\
\hline CAPR \& & 2 & -0.036 & 5 & 1.819 & 5 & $0.821 * * *$ \\
\hline CN \& & 1 & 0.165 & 2 & 0.031 & 5 & $0.842 * * *$ \\
\hline CR \& & 1 & -0.574 & 1 & -1.413 & 5 & $0.848 * * *$ \\
\hline CPI \& & 1 & -1.654 & 4 & -1.032 & 5 & $0.838 * * *$ \\
\hline DEBT \& & 2 & -0.955 & 31 & -0.827 & 5 & $0.838 * * *$ \\
\hline DEBTGDP & 3 & $-3.804 * * *$ & 17 & $-3.231 * *$ & 5 & $0.707 * *$ \\
\hline DEFGDP $\S$ & 0 & $-7.625 * * *$ & 2 & $-7.649 * * *$ & 1 & 0.244 \\
\hline DEFICITN $\S$ & 0 & $-7.443 * * *$ & 3 & $-7.421 * * *$ & 2 & 0.327 \\
\hline DEMAND \& & 1 & 1.057 & 5 & 1.127 & 5 & $0.840 * * *$ \\
\hline EMP \& & 0 & 1.039 & 2 & 0.798 & 5 & $0.790 * * *$ \\
\hline EXR \& & 0 & 1.948 & 5 & 2.538 & 5 & $0.832 * * *$ \\
\hline GDPDEF \& & 0 & -1.069 & 2 & -1.001 & 5 & $0.832 * * *$ \\
\hline GDPN \& & 1 & 0.310 & 4 & 0.540 & 5 & $0.834 * * *$ \\
\hline GDPR \& & 2 & 0.454 & 1 & -0.423 & 5 & $0.847 * * *$ \\
\hline EUR10Y & 1 & -2.555 & 2 & $-2.857 * *$ & 5 & $0.674 * *$ \\
\hline EUR3M & 1 & $-2.868 * *$ & 3 & -2.054 & 5 & $0.677 * *$ \\
\hline GDPEUR12 \& & 1 & -0.867 & 3 & -1.002 & 5 & $0.825^{* * *}$ \\
\hline GINVN \& & 1 & -0.314 & 7 & 0.781 & 5 & $0.842 * * *$ \\
\hline GINVR \& & 1 & -1.126 & 4 & -0.846 & 5 & $0.810 * * *$ \\
\hline GN \& & 0 & 1.213 & 2 & 1.157 & 5 & $0.839 * * *$ \\
\hline GR \& & 0 & -1.094 & 5 & -1.234 & 5 & $0.850 * * *$ \\
\hline HICPEUR12 \& & 0 & 2.360 & 5 & 2.142 & 5 & $0.841 * * *$ \\
\hline ILONGR & 0 & $-2.790 *$ & 1 & $-2.771 *$ & 5 & $0.704 * *$ \\
\hline IMPR \& & 1 & 1.239 & 5 & 1.527 & 5 & $0.830 * * *$ \\
\hline INCCORP \& & 3 & 1.644 & 42 & 0.886 & 5 & $0.806 * * *$ \\
\hline INCOME \& & 3 & -1.747 & 4 & -0.500 & 5 & $0.837 * * *$ \\
\hline INCOMER \& & 1 & -1.701 & 2 & -1.554 & 5 & $0.824 * * *$ \\
\hline INCTAX \& & 2 & 0.408 & 3 & 0.469 & 5 & $0.841 * * *$ \\
\hline INCTAXRATE \& & 2 & -0.731 & 3 & -1.918 & 5 & $0.832 * * *$ \\
\hline INFL \& & 0 & -0.525 & 0 & -0.525 & 5 & $0.571 * *$ \\
\hline INTEREST \& & 2 & -1.147 & 3 & -1.118 & 5 & $0.800 * * *$ \\
\hline INVENTR § & 1 & $-2.969 * *$ & 2 & $-4.926 * * *$ & 3 & 0.099 \\
\hline INVR \& & 1 & -1.129 & 5 & -0.577 & 5 & $0.807 * * *$ \\
\hline LFORCE \& & 0 & 0.306 & 2 & -0.229 & 4 & $0.718 * *$ \\
\hline LTIRLN \& & 1 & -0.417 & 1 & $-2.649 *$ & 5 & $0.747 * * *$ \\
\hline M3N \& & 0 & 0.259 & 5 & 0.144 & 5 & $0.831 * * *$ \\
\hline M3R \& & 0 & -1.250 & 4 & -1.300 & 5 & $0.834 * * *$ \\
\hline NAIRU \& & 18 & 0.261 & 3 & 0.482 & 5 & $0.800 * * *$ \\
\hline NETWAGEN \& & 0 & 0.265 & 3 & 0.308 & 5 & $0.841 * * *$ \\
\hline NETWAGER \& & 0 & -0.553 & 7 & -0.173 & 5 & $0.838 * * *$ \\
\hline PERSINCTAX \& & 2 & -0.987 & 7 & -0.963 & 5 & $0.832 * * *$ \\
\hline POP \& & 3 & -0.412 & 2 & -0.131 & 5 & $0.636 * *$ \\
\hline PRINVR \& & 1 & -1.223 & 2 & -0.853 & 5 & $0.799 * * *$ \\
\hline PROD \& & 1 & -1.691 & 1 & -1.903 & 5 & $0.836 * * *$ \\
\hline SITEUR \& & 3 & -2.579 & 3 & -2.080 & 5 & $0.832 * * *$ \\
\hline SITEURREAL \& & 4 & -2.112 & 2 & -1.605 & 5 & $0.606 * *$ \\
\hline SOCCOMP \& & 0 & 3.568 & 4 & 4.469 & 5 & $0.778 * * *$ \\
\hline SOCEMP \& & 2 & 0.696 & 17 & 0.729 & 5 & $0.845^{* * *}$ \\
\hline SOCEMPRATE $\S$ & 0 & $-4.240 * * *$ & 3 & $-4.229 * * *$ & 3 & 0.133 \\
\hline SOCTOTAL \& & 0 & 3.209 & 3 & 3.723 & 5 & $0.833 * * *$ \\
\hline STIRLN \& & 4 & -1.910 & 2 & $-2.904 *$ & 5 & $0.758 * * *$ \\
\hline
\end{tabular}




\begin{tabular}{|c|c|c|c|c|c|c|}
\hline Variable & \multicolumn{2}{|c|}{ ADF } & \multicolumn{2}{|c|}{$\mathbf{P P}$} & \multicolumn{2}{|c|}{ KPSS } \\
\hline & Lags (SIC) & & Bandwidth & & & \\
\hline TRANSFERSN \& & 0 & -0.448 & 1 & -0.462 & 5 & $0.839 * * *$ \\
\hline TREND_EMP \& & 0 & -1.005 & 1 & 0.937 & 5 & $0.817 * * *$ \\
\hline UCC & 0 & $-2.790 *$ & 1 & $-2.771 *$ & 5 & $0.704 * *$ \\
\hline ULC \& & 0 & -0.312 & 0 & -0.312 & 5 & $0.837 * * *$ \\
\hline UN \& & 1 & -0.593 & 3 & -0.315 & 5 & $0.746 * * *$ \\
\hline UR \& & 0 & 0.316 & 3 & -0.017 & 5 & $0.762 * * *$ \\
\hline UTIL $\S$ & 1 & $-3.889 * * *$ & 4 & $-4.817 * * *$ & 5 & 0.333 \\
\hline WEDGE \& & 2 & -0.932 & 35 & -1.576 & 5 & $0.841 * * *$ \\
\hline YPOT \& & 0 & 4.052 & 3 & 3.203 & 5 & $0.839 * * *$ \\
\hline
\end{tabular}

First Differences

\begin{tabular}{|c|c|c|c|c|c|c|}
\hline Variable & & & & & & \\
\hline & Lags (SIC) & & Bandwidth & & Bandwidth & \\
\hline AGWN § & 0 & $-5.010 * * *$ & 4 & $-4.977 * * *$ & 0 & 0.172 \\
\hline AGWR $\S$ & 0 & $-5.982 * * *$ & 11 & $-6.481 * * *$ & 10 & 0.169 \\
\hline $\mathrm{CAN} \S$ & 0 & $-11.015 * * *$ & 9 & $-14.202 * * *$ & 7 & 0.094 \\
\hline CAGDP $\S$ & 0 & $-11.923 * * *$ & 11 & $-16.463 * * *$ & 11 & 0.159 \\
\hline CAPR & 1 & -2.292 & 0 & $-2.740 *$ & 5 & $0.453^{*}$ \\
\hline CAPR, 2nd diff. $\S$ & 0 & $-10.407 * * *$ & 1 & $-10.223 * * *$ & 4 & 0.154 \\
\hline $\mathrm{CN} \S$ & 2 & $-8.637 * * *$ & 2 & $-8.865^{* * *}$ & 2 & 0.115 \\
\hline $\mathrm{CR} \S$ & 0 & $-8.034 * * *$ & 4 & $-8.982 * * *$ & 1 & 0.101 \\
\hline CPI $\S$ & 0 & $-4.311 * * *$ & 3 & $-4.408 * * *$ & 4 & 0.240 \\
\hline DEBT $\S$ & 1 & $-7.752 * * *$ & 18 & $-12.795 * * *$ & 34 & $0.383^{*}$ \\
\hline DEBTGDP $\S$ & 2 & $-5.682 * * *$ & 14 & $-8.940 * * *$ & 16 & $0.400 *$ \\
\hline DEFGDP $\S$ & 2 & $-8.571 * * *$ & 31 & $-35.378 * * *$ & 16 & 0.211 \\
\hline DEFICITN $\S$ & 2 & $-8.221 * * *$ & 41 & $-37.986^{* * *}$ & 19 & 0.226 \\
\hline DEMAND $\S$ & 0 & $-12.001 * * *$ & 2 & $-12.683 * * *$ & 4 & 0.207 \\
\hline EMP $\S$ & 0 & $-5.392 * * *$ & 2 & $-5.417 * * *$ & 3 & 0.235 \\
\hline EXR & 0 & $-6.342 * * *$ & 2 & $-6.346^{* * *}$ & 0 & $0.484 * *$ \\
\hline GDPDEF § & 0 & $-6.014 * * *$ & 3 & $-6.014 * * *$ & 2 & 0.228 \\
\hline GDPN § & 0 & $-8.909 * * *$ & 4 & $-8.781 * * *$ & 4 & 0.226 \\
\hline GDPR $\S$ & 1 & $-7.046^{* * *}$ & 1 & $-11.026 * * *$ & 0 & 0.026 \\
\hline EUR10Y $\S$ & 2 & $-4.250 * * *$ & 2 & $-4.196 * * *$ & 3 & 0.307 \\
\hline EUR3M $\S$ & 2 & $-3.774 * * *$ & 2 & $-3.860 * * *$ & 3 & 0.147 \\
\hline GDPEUR12 § & 0 & $-3.538 * *$ & 0 & $-3.538 * *$ & 4 & 0.189 \\
\hline GINVN § & 0 & $-8.783 * * *$ & 18 & $-17.223 * * *$ & 8 & 0.240 \\
\hline GINVR § & 0 & $-8.922 * * *$ & 15 & $-15.151 * * *$ & 11 & 0.169 \\
\hline GN $\S$ & 0 & $-6.224 * * *$ & 1 & $-6.224 * * *$ & 2 & 0.332 \\
\hline GR $\S$ & 0 & $-20.327 * * *$ & 3 & $-19.921 * * *$ & 7 & 0.185 \\
\hline HICPEUR12 & 2 & -1.334 & 5 & $-6.414 * * *$ & 5 & $0.397 *$ \\
\hline ILONGR § & 0 & $-5.341 * * *$ & 5 & $-5.297 * * *$ & 5 & 0.251 \\
\hline IMPR $\S$ & 0 & $-11.771 * * *$ & 2 & $-12.264 * * *$ & 4 & 0.304 \\
\hline INCCORP $\S$ & 2 & $-6.175 * * *$ & 30 & $-16.908 * * *$ & 28 & $0.352 *$ \\
\hline INCOME $\S$ & 2 & $-2.696^{*}$ & 4 & $-7.954 * * *$ & 4 & 0.158 \\
\hline INCOMER $\S$ & 0 & $-8.854 * * *$ & 3 & $-8.742 * * *$ & 3 & 0.180 \\
\hline INCTAX § & 1 & $-8.038 * * *$ & 4 & $-14.938 * * *$ & 3 & 0.104 \\
\hline INCTAXRATE $\S$ & 1 & $-8.939 * * *$ & 18 & $-38.496 * * *$ & 11 & 0.124 \\
\hline INFL $\S$ & 0 & $-6.324 * * *$ & 1 & $-6.295 * * *$ & 2 & 0.117 \\
\hline INTEREST $\S$ & 1 & $-9.341 * * *$ & 4 & $-14.501 * * *$ & 2 & 0.091 \\
\hline INVENTR $\S$ & 0 & $-11.701 * * *$ & 5 & $-12.952 * * *$ & 12 & 0.144 \\
\hline INVR $\S$ & 0 & $-10.080 * * *$ & 3 & $-10.611 * * *$ & 5 & 0.102 \\
\hline LFORCE $\S$ & 0 & $-4.742 * * *$ & 0 & $-4.742 * * *$ & 2 & 0.171 \\
\hline LTIRLN $\S$ & 0 & $-10.031 * * *$ & 1 & $-9.420 * * *$ & 9 & 0.208 \\
\hline $\mathrm{M} 3 \mathrm{~N} \S$ & 2 & -1.898 & 5 & $-6.858 * * *$ & 5 & 0.142 \\
\hline M3R $\S$ & 0 & $-7.333 * * *$ & 4 & $-7.284 * * *$ & 4 & 0.164 \\
\hline
\end{tabular}




\begin{tabular}{|c|c|c|c|c|c|c|}
\hline Variable & \multicolumn{2}{|c|}{ ADF } & \multicolumn{2}{|c|}{ PP } & \multicolumn{2}{|c|}{ KPSS } \\
\hline & Lags (SIC) & & Bandwidth & & andwid & \\
\hline NAIRU § & 15 & $-3.413 * *$ & 3 & $-7.203 * * *$ & 3 & $0.362 *$ \\
\hline NETWAGEN \& & 0 & $-6.985 * * *$ & 3 & $-7.002 * * *$ & 3 & 0.106 \\
\hline NETWAGER § & 0 & $-7.289 * * *$ & 7 & $-8.737 * * *$ & 7 & 0.090 \\
\hline PERSINCTAX $\S$ & 1 & $-7.850 * * *$ & 16 & $-22.007 * * *$ & 21 & 0.306 \\
\hline POP $\S$ & 1 & $-4.285^{* * *}$ & 4 & $-3.530 * *$ & 2 & 0.213 \\
\hline PRINVR $\S$ & 0 & $-10.287 * * *$ & 1 & $-10.682 * * *$ & 1 & 0.058 \\
\hline PROD $\S$ & 0 & $-10.496 * * *$ & 1 & $-10.828 * * *$ & 2 & 0.279 \\
\hline SITEUR $\S$ & 2 & $-2.615 *$ & 3 & $-5.163 * * *$ & 1 & $0.386 *$ \\
\hline SITEURREAL $\S$ & 2 & $-3.655^{* * *}$ & 1 & $-6.369 * * *$ & 7 & 0.094 \\
\hline SOCCOMP & 0 & $-5.224 * * *$ & 4 & $-5.450 * * *$ & 4 & $0.598 * *$ \\
\hline SOCEMP § & 1 & $-6.886^{* * *}$ & 14 & $-10.982 * * *$ & 17 & 0.224 \\
\hline SOCEMPRATE $\S$ & 0 & $-7.036^{* * *}$ & 8 & $-8.870 * * *$ & 9 & 0.175 \\
\hline SOCTOTAL & 0 & $-5.632 * * *$ & 3 & $-5.759 * * *$ & 4 & $0.577 * *$ \\
\hline STIRLN § & 0 & $-9.934 * * *$ & 1 & $-9.284 * * *$ & 10 & 0.267 \\
\hline TRANSFERSN § & 0 & $-8.967 * * *$ & 1 & $-9.049 * * *$ & 1 & 0.076 \\
\hline TREND_EMP $\S$ & 0 & $-5.668 * * *$ & 2 & $-5.690 * * *$ & 2 & 0.235 \\
\hline UCC $\S$ & 0 & $-5.341 * * *$ & 5 & $-5.297 * * *$ & 5 & 0.251 \\
\hline ULC $\S$ & 0 & $-7.134 * * *$ & 1 & $-7.141 * * *$ & 1 & 0.091 \\
\hline UN $\S$ & 0 & $-4.137 * * *$ & 0 & $-4.137 * * *$ & 3 & 0.168 \\
\hline UR $\S$ & 0 & $-4.555^{* * *}$ & 2 & $-4.554 * * *$ & 3 & 0.200 \\
\hline UTIL & 1 & $-6.262 * * *$ & 3 & $-10.308 * * *$ & 3 & $0.568 * *$ \\
\hline WEDGE $\S$ & 0 & $-9.054 * * *$ & 12 & $-12.015 * * *$ & 25 & $0.402 *$ \\
\hline YPOT & 0 & $-3.968 * * *$ & 3 & $-3.957 * * *$ & 4 & $0.557 * *$ \\
\hline
\end{tabular}

Thus it turns out that most level variables are I(1). We also tested for cointegration between those time series where we suspected long-run relations to hold. In those cases where cointegration seemed to be present, we used error-correction models as dynamic specifications for these relations while estimations in levels or first differences were tried when tests indicated absence of longrun relations between stationary or I(1) variables, respectively. In the following, we show the results of successful cointegration tests for the behavioral equations finally adopted. *,**,*** means that the null hypothesis (ADF and Phillips-Perron: no stationarity of the residuals; KPSS: stationarity of the residuals) can be rejected at the 10, 5, 1 percent level of significance, respectively.

\section{Tests For Cointegration - Tests For Stationarity Of Residuals Of The Equations}

\begin{tabular}{|c|c|c|c|}
\hline Equation & ADF & Phillips-Perron & KPSS \\
\hline Potential GDP (production function) & $-4.197 * * *$ & $-4.199 * * *$ & 0.139 \\
\hline Private consumption & $-7.142 * * *$ & $-7.122 * * *$ & 0.087 \\
\hline Fixed capital formation & $-3.877 * * *$ & $-3.558 * *$ & 0.086 \\
\hline Inventory investment & $-8.606 * * *$ & $-8.380 * * *$ & 0.086 \\
\hline Equation & ADF & Phillips-Perron & KPSS \\
\hline Exports & $-4.988 * * *$ & $-4.896 * * *$ & 0.148 \\
\hline Imports & $-6.826 * * *$ & $-6.820 * * *$ & 0.108 \\
\hline Employment & $-3.565 * *$ & $-3.619 * * *$ & 0.065 \\
\hline Labor supply & $-6.384 * * *$ & $-6.384 * * *$ & 0.123 \\
\hline Wage rate & $-4.937 * * *$ & $-4.814 * * *$ & 0.071 \\
\hline Consumer price index & $-3.740 * * *$ & $-5.049 * * *$ & 0.059 \\
\hline GDP deflator & $-5.928 * * *$ & $-5.918 * * *$ & 0.310 \\
\hline Real money demand & $-5.906 * * *$ & $-5.935 * * *$ & 0.122 \\
\hline Short-term interest rate (flex. exchange rate) & $-2.791 * * *$ & $-2.897 * * *$ & 0.158 \\
\hline Short-term interest rate (fixed exchange rate) & $-5.057 * * *$ & $-3.460 * * *$ & 0.323 \\
\hline Long-term interest rate & $-2.412 * *$ & $-2.587 * *$ & 0.227 \\
\hline Exchange rate & $-3.565 * *$ & $-5.373 * * *$ & 0.155 \\
\hline Soc. sec. contr. by companies & $-5.455 * * *$ & $-6.483 * * *$ & 0.103 \\
\hline Corporate taxes & $-5.388 * * *$ & $-5.393 * * *$ & 0.136 \\
\hline Balance of other government exp. and rev. & $-6.196 * * *$ & $-6.475 * * *$ & 0.125 \\
\hline Interest payments on public debt & $-6.002 * * *$ & $-6.038 * * *$ & 0.192 \\
\hline Government consumption & $-4.735 * * *$ & $-4.739 * * *$ & 0.114 \\
\hline
\end{tabular}




\section{MODEL EQUATIONS}

The model combines Keynesian and neoclassical elements. The former determine the short and medium run solutions in the sense that the model is demand driven and persistent disequilibria in the goods and labor markets are possible. The supply side incorporates neoclassical features. Almost all behavioral equations are specified in error correction form, except for the equations determining the exchange rate, the interest rates, changes in inventories, the NAIRU and potential GDP. In this section, the behavioral equations are first described very briefly. The model equations are then presented in detail. For a more extensive discussion of an earlier version, see Weyerstrass et al. (2001).

Consumption of private households is explained by disposable income and by the real long-term interest rate, the latter reflecting wealth effects. Investment is derived from profit maximization of firms. Real gross fixed capital formation is thus influenced by total final demand and by the user cost of capital (the real long-term interest rate plus the depreciation rate of the capital stock). Real exports of goods and services are a function of the real exchange rate and of foreign demand for Slovenian goods and services. As the aggregate Euro Area is by far Slovenia's largest trading partner, accounting for about 60 percent of Slovenian foreign trade, the other 12 Euro Area countries approximate the rest of the world ${ }^{1}$. Therefore, foreign demand is measured by Euro Area real GDP, and only the exchange rate between the Slovenian currency tolar and the euro is considered. Slovenian real imports of goods and services depend on final domestic demand. A significant influence of the real exchange rate on imports was not supported by the data.

Money demand depends on real GDP and on the short-term interest rate. The long-term interest rate is linked to the short-term rate in a term structure equation. In addition, the long-term interest rate in Slovenia depends on its Euro Area counterpart, reflecting Slovenia's integration in the European capital market. The exchange rate equation rests on considerations of the uncovered interest parity and the purchasing power parity theories: the nominal exchange rate between the Slovenian tolar and the euro depends on the interest differential between Slovenia and the Euro Area and on the ratio of the price levels of both countries/regions.

Labor demand (actual employment) is influenced by real GDP and by unit labor cost, where the latter are defined as the ratio of the nominal gross wage and labor productivity. Labor productivity is defined as real GDP per employee. Labor supply depends on the real net wage and on real GDP. The latter influence is to approximate the "discouraged worker effect": in an economic downturn, increasing unemployment discourages people from actively seeking employment. On the other hand, in an upturn, improving labor market conditions encourage more people to enter the labor market. The wage rate is determined by the price level, the unemployment rate, labor productivity, and the tax wedge on labor income, the latter being defined as the sum of income taxes and employees' social security contributions. Consumer prices depend on domestic and international factors. The former are made up by unit labor costs. Imported inflation is approximated by the nominal exchange rate of the Slovenian tolar vis-à-vis the euro. This specification shall account for the fact that a depreciation of the domestic currency raises import prices. The GDP deflator is linked to the consumer price index.

Potential output, which is determined by a Cobb-Douglas production function with constant returns to scale, depends on trend employment, the capital stock, and autonomous technical progress. Trend employment is defined as the labor force minus natural unemployment. The NAIRU (or inflation-stable unemployment rate) is modeled by first applying a band-pass filter to the actual unemployment rate in order to extract the trend. In the simulations, the NAIRU is then modeled as an AR(8)-process.

Government expenditures and revenues are linked to economic policy instruments and to the economic situation in Slovenia, which is approximated by GDP at current prices. Revenues from personal income taxes and from employees' social security contributions are determined by multiplying the tax rate and the social security contribution rate, respectively, by the number of employees and by the average gross wage per employee. In a behavioral equation, corporate income taxes are explained by GDP. Interest payments on public debt depend on the

\footnotetext{
${ }^{1}$ In the estimation period, Slovenia did not belong to the Euro Area.
} 
debt level and the long-term interest rate. The difference between the remaining government revenues and expenditures is explained by the lagged debt level. This specification shall approximate a fiscal rule according to which the primary budget surplus is increased if debt rose in the previous period. Such a rule shall guarantee long run fiscal sustainability by preventing an ever increasing debt level. Government consumption and investment as well as transfers to private households are regarded as policy instruments. The budget deficit is given by the difference between total government expenditures and revenues.

\section{Behavioral Equations}

$R^{2}$ is the adjusted coefficient of determination, DW is the Durbin Watson statistic; t-statistics are given in parentheses below coefficients.

Potential output

$\log (Y P O T)=-0.839136+0.648102 * \log \left(T R E N D \_E M P\right)+(1-0.648102) * \log (C A P R)+0.004365 *$ TIME

$\begin{aligned} \log (G D P R)= & -0.839136+0.648102 * \log (E M P)+(1-0.648102) * \log (C A P R)+0.004365 * \text { TIME } \\ (-2.548920)(3.625960) & (3.625960)\end{aligned}$

$R^{2}=0.986289 \quad \mathrm{DW}=0.801470$

NAIRU

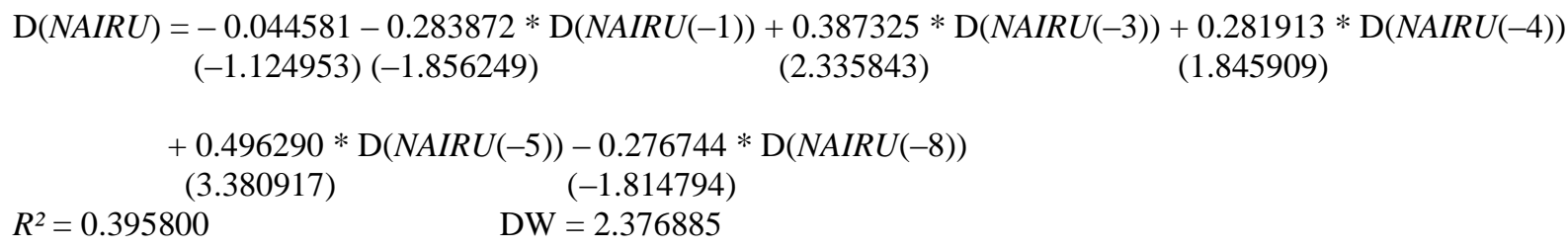

Consumption of private households

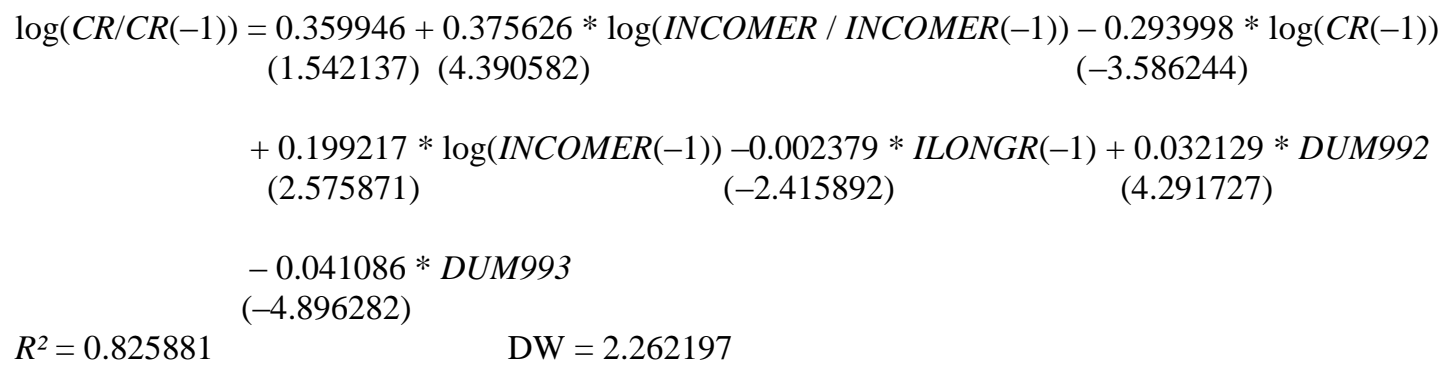

Gross fixed capital formation

$\log ($ PRINVR / PRINVR $(-4))=0.547377+1.677160 * \log ($ DEMAND $/$ DEMAND $(-4))-0.582231 * \log ($ PRINVR $(-4))$ $(0.572847)(5.306386) \quad(-4.372626)$

$R^{2}=0.781110 \quad \mathrm{DW}=0.960741$ 
Inventory investment

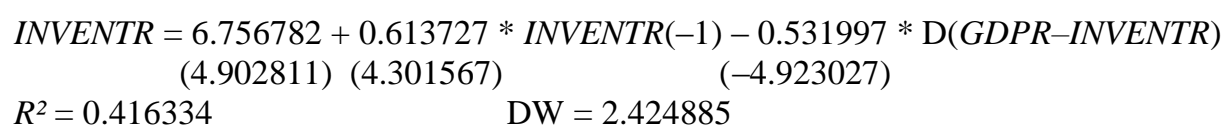

Imports of goods and services

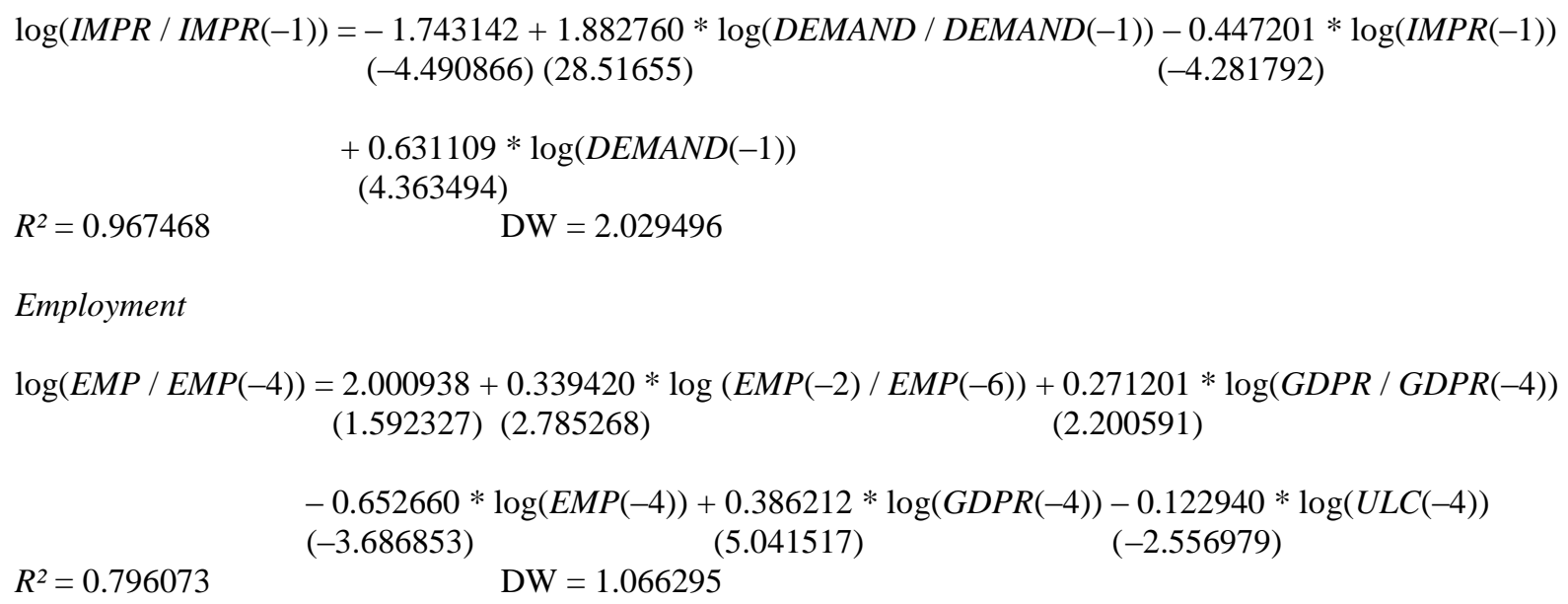


Labor supply

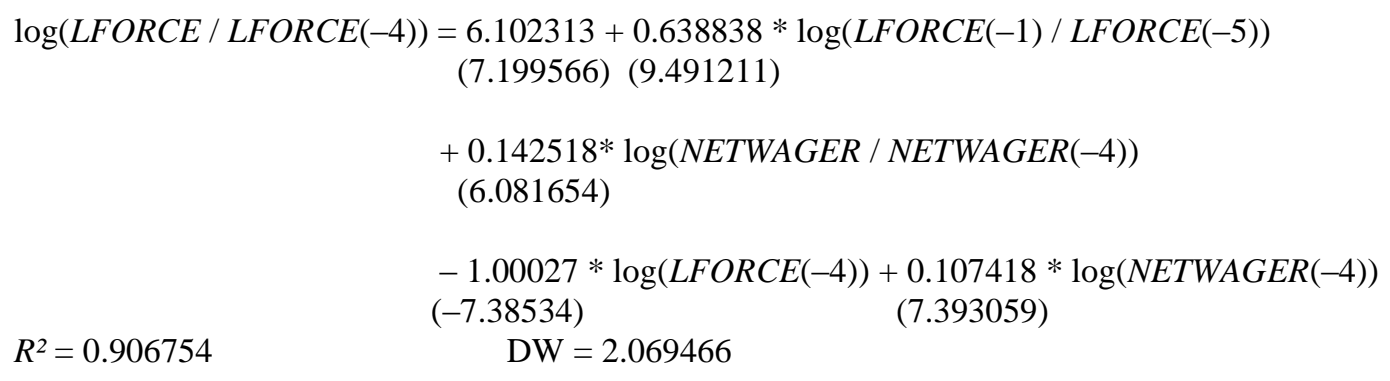

Wage rate

$\log (A G W N / A G W N(-4))=0.082167+0.432615 * \log (A G W N(-1) / A G W N(-5))+0.446809 * \log (C P I / C P I(-4))$ (0.226989) (4.616714) (3.392647)

Consumer price index

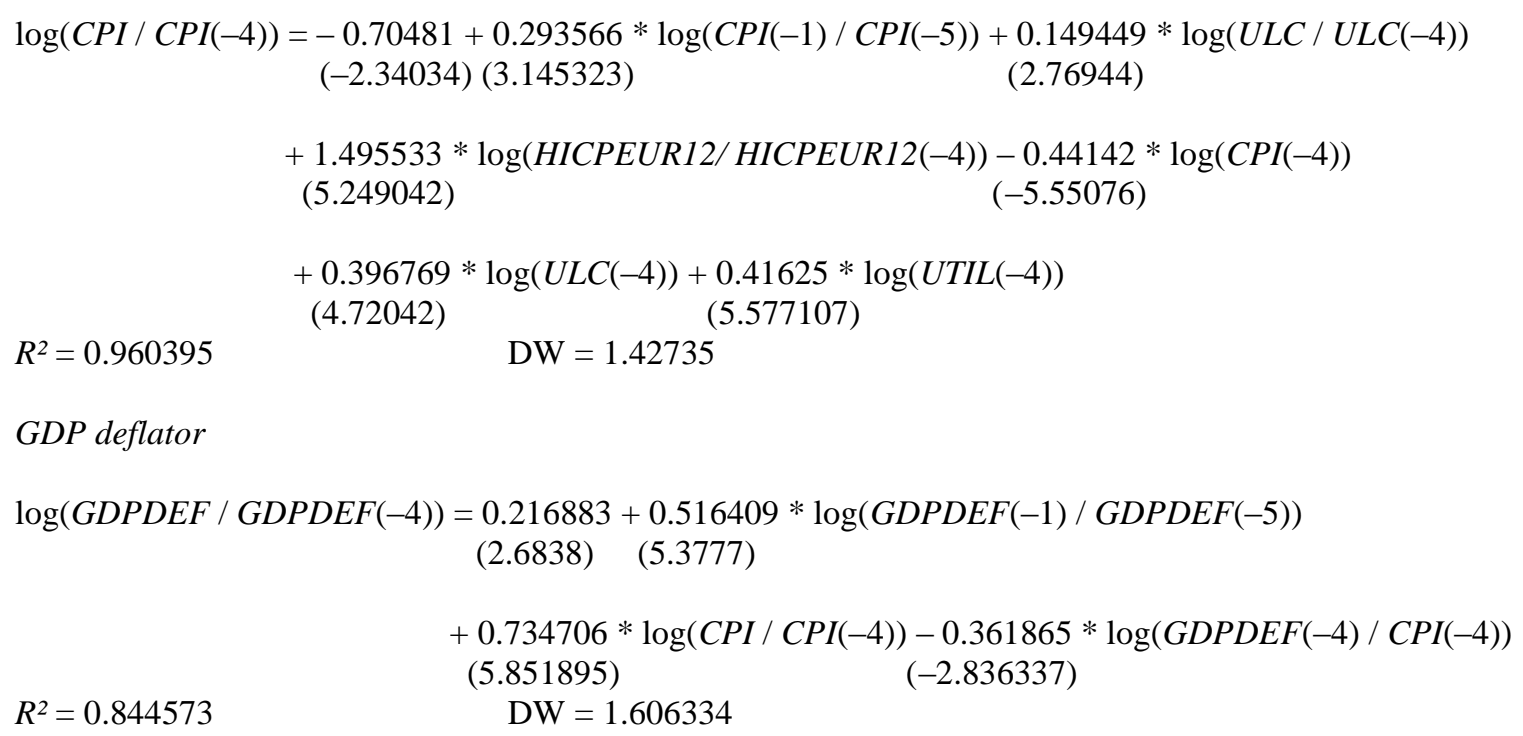


Real money demand

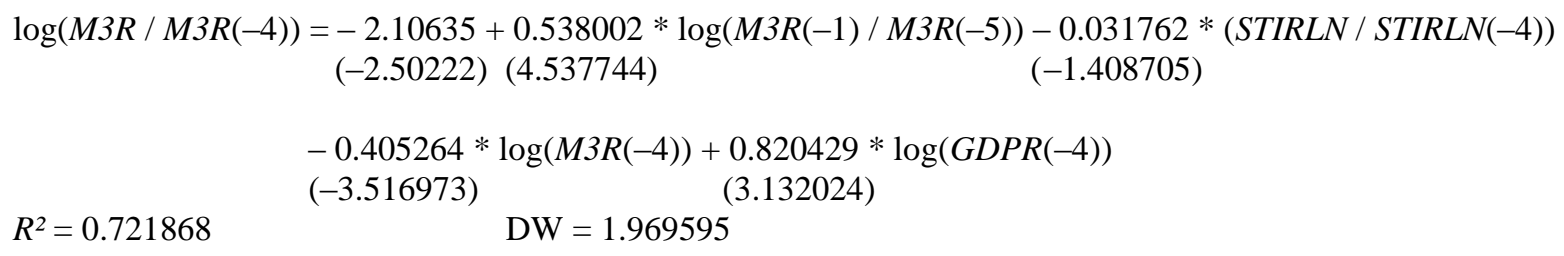

Short term interest rate

$(\operatorname{STIRLN}-\operatorname{STIRLN}(-4))=1.292312 * \operatorname{INFL}+0.418398 *(G R G D P R-G R Y P O T)$ $(10.55622) \quad(2.220118)$

$R^{2}=0.797275$ $-0.905898 *(\operatorname{STIRLN}(-4)-\operatorname{EUR} 3 M(-4))$ $(-11.96319)$

$\mathrm{DW}=0.684259$

Exchange rate

$($ SITEUR / 100 $)=0.212657-0.001893 *($ LTIRLN - EURIOY $)+2.184844 *($ CPI / HICPEUR12 $)$ (5.46069) (-2.027690) (61.08336)

$R^{2}=0.996093 \quad \mathrm{DW}=0.895409$

Social security contributions by companies

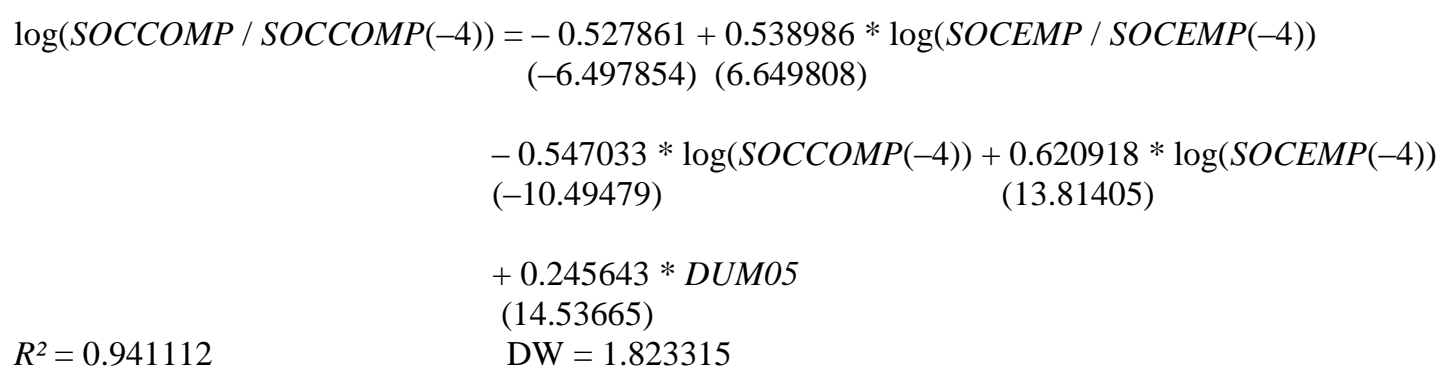


Corporate taxes

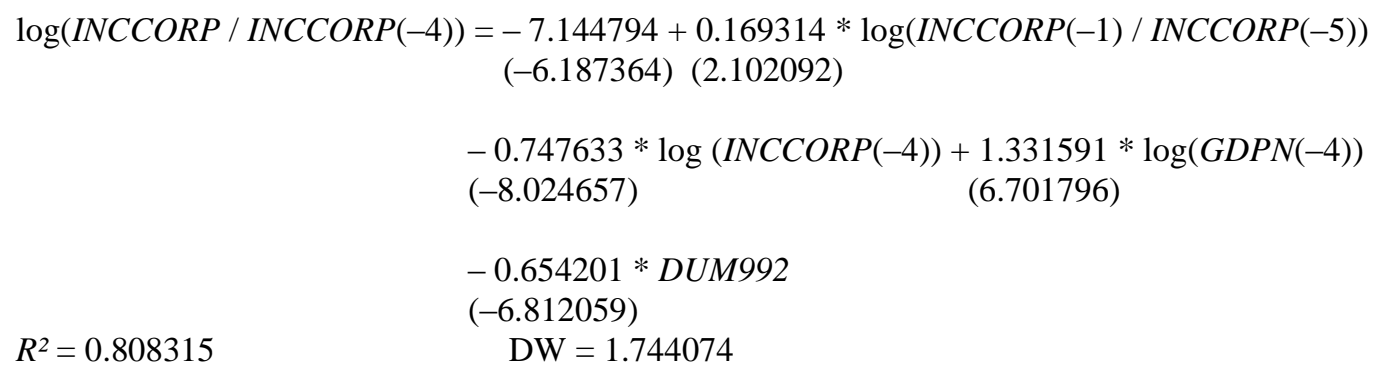

Balance of other government revenues and expenditures

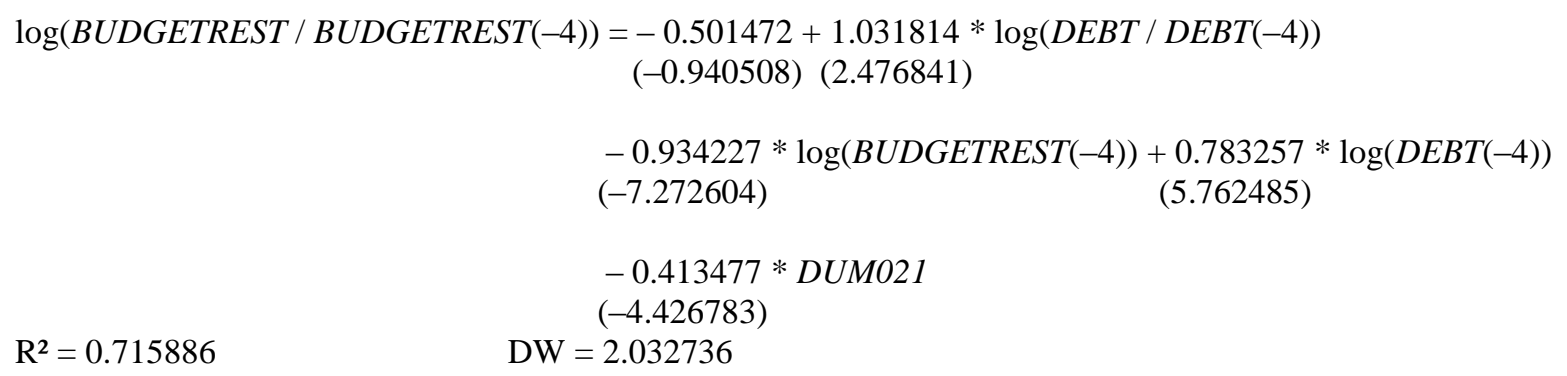

Short term interest rate in model version with fixed exchange rates

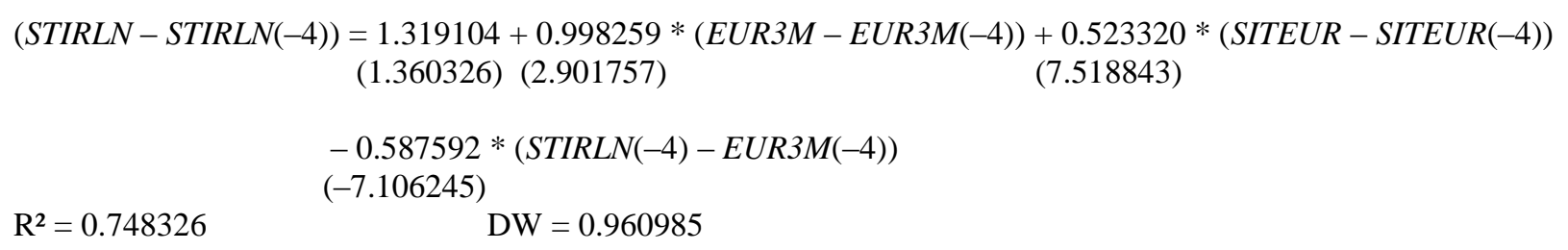




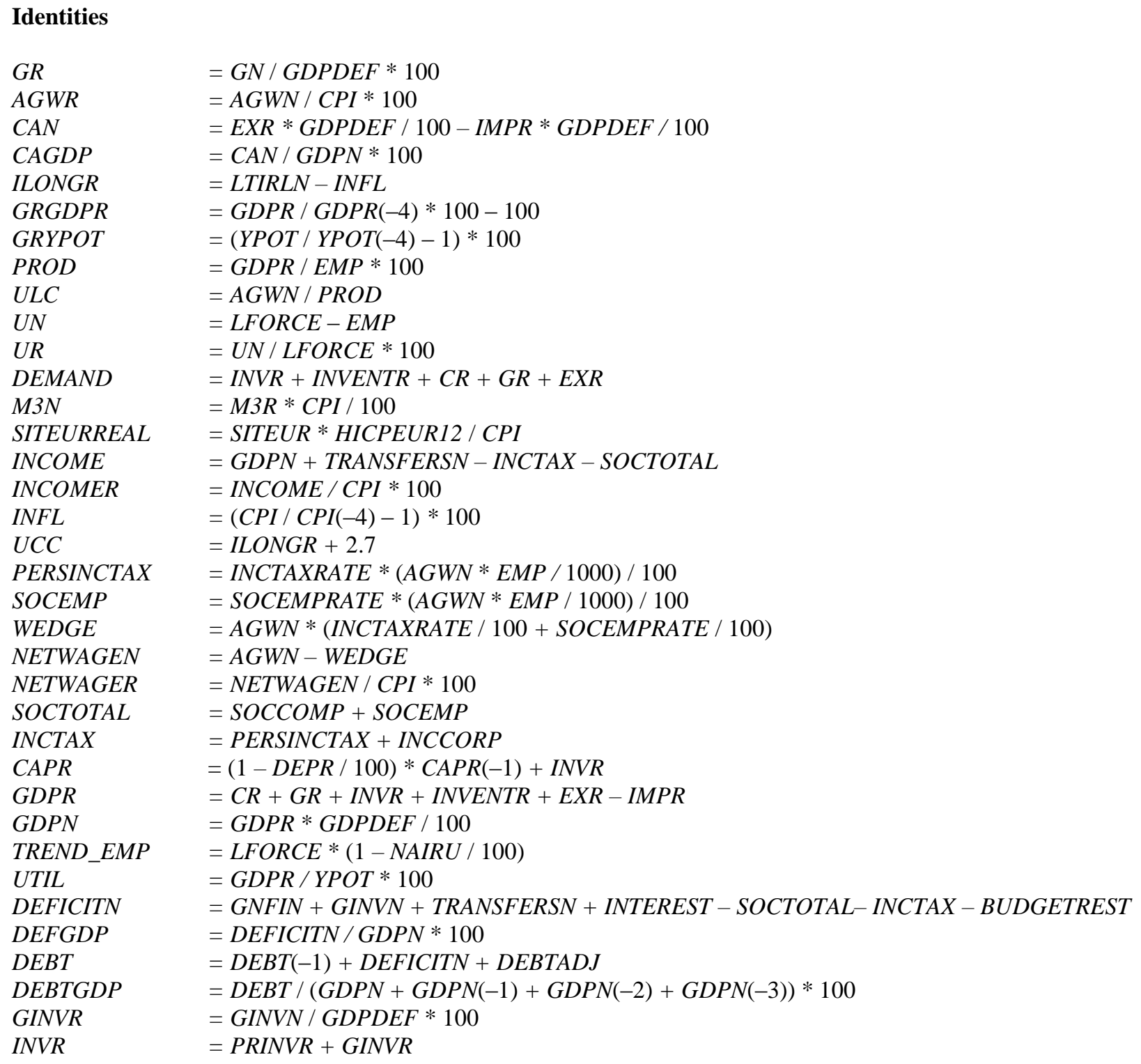

\section{CONCLUDING REMARKS}

The model SLOPOL6 as described in the previous Section was obtained after a series of steps in a trialand-error process, following the general-to-specific methodology initiated by David Hendry and associates (see, e.g., Hendry 1995). We also conducted simulations of the model (both static and dynamic) with historical values of (non-controllable and policy) exogenous variables over the period of estimation and found reasonable tracking quality for most variables with respect to trends and turning points. This encourages us to use the model (even more than its predecessors) for policy analysis.

So far, we used SLOPOL6 for simulation analyses to answer two questions: First, we asked whether Slovenia's choice of participating in the exchange rate mechanism of the European Monetary System II (ERM-II) soon after EU accession was the best strategy in terms of the macroeconomic performance (Weyerstrass and Neck 2007a). We found that a better overall economic performance could have been achieved under a crawling peg 
regime allowing a depreciation of the Slovenian tolar before introducing the euro in 2007. The worst policy results were obtained when the exchange rate was totally fixed at an early stage of EMU integration. Moreover, we showed that the labor market performance could be significantly improved by cutting income taxes and social security contribution rates.

The second application of SLOPOL6 examines which macroeconomic effects can be expected from Slovenia's adoption of the euro as legal tender (Weyerstrass and Neck 2007b). It was shown that Euro Area accession might bring about temporarily higher real GDP growth, a permanently higher GDP level, more employment, temporarily lower inflation and a permanently lower price level. On the other hand, both public finances and the current account might deteriorate. Hence, in contrast to the path towards abandoning the national currency tolar for the euro, which posed problems of adjustment, the (mostly supply-side) effects of the eventual Slovenian membership in the Euro Area will have mainly advantages for the Slovenia economy. These insights were obtained with the help of the SLOPOL6 macroeconometric model, and we are convinced that it can also be used to deal with other economic policy problems for Slovenia.

\section{ACKNOWLEDGMENT}

Financial support by the province of Carinthia, Klagenfurt University and by the Jubiläumsfonds of the Austrian National Bank (project no. 12166) is gratefully acknowledged. The opinions presented need not be those of the Austrian National Bank.

\section{REFERENCES}

1. Hendry, D. (1995), Dynamic Econometrics. Oxford: Oxford University Press.

2. Neck, R., K. Weyerstrass, G. Haber (2004), Policy Recommendations for Slovenia: A Quantitative Economic Policy Approach; in: Böhm, B., Frisch, H., Steiner M. (eds.), Slovenia and Austria: Bilateral Economic Effects of Slovenian EU Accession, Graz: Leykam, 249-271.

3. Weyerstrass, K., G. Haber, R. Neck (2001), SLOPOL1: A Macroeconomic Model for Slovenia. International Advances in Economic Research 7 (1), 20-37.

4. Weyerstrass, K., R. Neck (2007a), A New EU Country on the Road to the Euro Area: Monetary and Fiscal Policies for Slovenia. To appear in Atlantic Economic Journal.

5. Weyerstrass, K., R. Neck (2007b), Macroeconomic Effects of Slovenia's Integration in the Euro Area. Discussion Paper, University of Klagenfurt, Klagenfurt. 